\title{
Front Matter: Volume 11654
}

, "Front Matter: Volume 11654," Proc. SPIE 11654, High-Speed Biomedical Imaging and Spectroscopy VI, 1165401 (14 April 2021); doi:

$10.1117 / 12.2596634$

SPIE. Event: SPIE BiOS, 2021, Online Only 


\section{PROGRESS IN BIOMEDICAL OPTICS AND IMAGING}

\section{High-Speed Biomedical Imaging and Spectroscopy VI}

Kevin K. Tsia

Keisuke Goda

Editors

6-11 March 2021

Online Only, United States

Sponsored and Published by

SPIE 
The papers in this volume were part of the technical conference cited on the cover and title page. Papers were selected and subject to review by the editors and conference program committee. Some conference presentations may not be available for publication. Additional papers and presentation recordings may be available online in the SPIE Digital Library at SPIEDigitalLibrary.org.

The papers reflect the work and thoughts of the authors and are published herein as submitted. The publisher is not responsible for the validity of the information or for any outcomes resulting from reliance thereon.

Please use the following format to cite material from these proceedings:

Author(s), "Title of Paper," in High-Speed Biomedical Imaging and Spectroscopy VI, edited by Kevin K. Tsia, Keisuke Goda, Proceedings of SPIE Vol. 11654 (SPIE, Bellingham, WA, 2021) Seven-digit Article CID Number.

ISSN: 1605-7422

ISSN: 2410-9045 (electronic)

ISBN: 9781510641433

ISBN: 9781510641440 (electronic)

Published by

SPIE

P.O. Box 10, Bellingham, Washington 98227-0010 USA

Telephone +1 3606763290 (Pacific Time) · Fax +1 3606471445

SPIE.org

Copyright (c) 2021, Society of Photo-Optical Instrumentation Engineers.

Copying of material in this book for internal or personal use, or for the internal or personal use of specific clients, beyond the fair use provisions granted by the U.S. Copyright Law is authorized by SPIE subject to payment of copying fees. The Transactional Reporting Service base fee for this volume is $\$ 21.00$ per article (or portion thereof), which should be paid directly to the Copyright Clearance Center (CCC), 222 Rosewood Drive, Danvers, MA 01923. Payment may also be made electronically through CCC Online at copyright.com. Other copying for republication, resale, advertising or promotion, or any form of systematic or multiple reproduction of any material in this book is prohibited except with permission in writing from the publisher. The CCC fee code is $1605-$ $7422 / 21 / \$ 21.00$.

Printed in the United States of America by Curran Associates, Inc., under license from SPIE.

Publication of record for individual papers is online in the SPIE Digital Library.

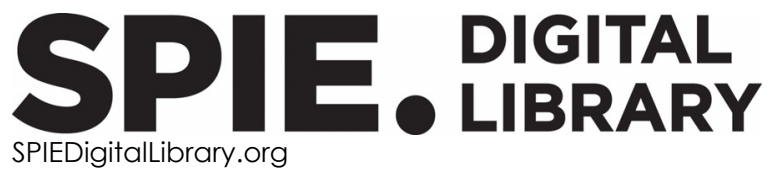

Paper Numbering: Proceedings of SPIE follow an e-First publication model. A unique citation identifier (CID) number is assigned to each article at the time of publication. Utilization of CIDs allows articles to be fully citable as soon as they are published online, and connects the same identifier to all online and print versions of the publication. SPIE uses a seven-digit CID article numbering system structured as follows:

- The first five digits correspond to the SPIE volume number.

- The last two digits indicate publication order within the volume using a Base 36 numbering system employing both numerals and letters. These two-number sets start with $00,01,02,03,04$, 05, 06, 07, 08, 09, 0A, OB ... 0Z, followed by 10-1Z, 20-2Z, etc. The CID Number appears on each page of the manuscript. 


\section{Contents}

HIGHSPEED PHOTOACOUSTIC IMAGING

1165409 High speed super-resolution localization photoacoustic mic roscopy [11654-28]

HIGHSPEED MULTIPHOTON IMAG ING II

11654 OD Fast, sensitive dual-comb CARS spectroscopy with a quasi-dual-comb laser [11654-23]

EMERGING TECHNOLOGIES I

11654 0] Single-shot compressed ultrafast photography in the ultraviolet spectral range [11654-9]

$11654 \mathrm{OL}$ Single-shot real-time optical imaging using compressed optical-streaking ultra-high-speed photography [11654-11]

EMERGING TECHNOLOGIES II

$11654 \mathrm{OV} \quad$ High-speed tracking of single biomolecules with angstrom localization precision and multicolor imaging capability (Invited Paper) [11654-13]

\section{POSTER SESSON}

1165417 Development of a real-time spectral imaging system using in-site micro-LED-based illumination and high-speed micro-camera for endoscopic applications [11654-40]

1165419 Non-invasive high-speed isotopic Raman spectroscopy for biomedical applications [11654-42] 
Proc. of SPIE Vol. 11654 1165401-4

\section{Downloaded From: https://www.spiedigitallibrary.org/conference-proceedings-of-spie on 25 Apr 2023
Terms of Use: https://www.spiedigitallibrary.org/terms-of-use}

